\title{
JOHN PAUL II CENTENNIAL INTERNATIONAL CONFERENCE
}

\author{
January 16-18, 2020 \\ University of San Jose-Recoletos \\ Cebu City, Philippines
}

Organized by: Philippine National Philosophical Research Society, Societas Ethica Philosophica and Rogationist College Seminary - Cebu

\section{GENERAL PROGRAM}

\section{January 16, 2020 Day 1}

\section{AM Sessions}

7:30 - 9:00 Registration

9:00 - 9:30 Opening Program

Doxology USJ-R Chorale

National Anthem USJ-R Chorale

Welcome Messages Rev. Fr. Cristopher C. Maspara, OAR USJ-R President

Most Rev. Midyphil B. Billones, D.D. Auxiliary Bishop of Cebu

Opening Remarks Rev. Fr. Francis Paul S. Escano, RCJ SEPI President

Conference Rationale Dr. Jove Jim S. Aguas - PNRPS Executive Governor

9:30 - 9:45 Break/Group Picture Taking

9:45 - 10:45 First Plenary Session Moderator: Dr. Jove Jim S. Aguas Msgr. Marek Slomka, PhD, Dsc - John Paul II Catholic University of Lublin - Poland

From Ideological Fundamentalism to Critical Openness:

The Urgent Challenge for Religion and Science

10:45 - 12:15 Second Plenary Session Moderator: Dr. Fleurdeliz AltezAlbela 


\section{$12: 15-1: 15$ \\ PM Sessions}

Lunch

\section{$1: 15-2: 45$}

$2: 45-4: 15$

$4: 15-4: 30$

$4: 30-6: 00$

$6: 00-8: 00$

\section{January 17, 2020}

$7: 00-7: 30$

Third Plenary Session Moderator: Dr. Juan Rafael G.

\section{Macaranas}

Prof. Jove Jim S. Aguas, PhD - University of Santo

Tomas - Philippines

The Philosophical Basis of John Paul II's Theology of the Body: Preliminary Analysis

Rev. Fr. Jose Adriand Emmanuel L. Layug, Ph.D. Immaculate Conception Major Seminary (Bulacan) Philippines

St. Karol Wojtyla and St. Edith Stein on Human Individuality: "Pausing at the Irreducible" and Why Think About It

First Concurrent Sessions A, B \& C

Break

Second Concurrent Sessions A, B \& C

Socials and Dinner (optional)

AM Sessions

8:00-9:30

$9: 30-9: 40$

Third Concurrent Sessions A, B, C\& D

Break

9:40 - 11:10 Fourth Plenary Session Moderator: Dr. Ferdinand

Mangibin

Rev. Fr. Patrick Gnanapragasam, PhD. - University of Madras, India

John Paul II on Dialogue of Faith and Reason: What can be learnt from it for Religious Studies in India / Asia? 
11:10 - 12:40 Fourth Concurrent Sessions A, B, C \& D

12:40-1:30 Lunch

PM Sessions

1:30 - 1:50 Launching of John Paul II Society of the Philippines (JPSP)

1:50 - 3:20 Fifth Plenary Session Moderator: Dr. Danilo S. Alterado

(Via Teleconference)

Dr. Michal Valčo - Presov University, Slovakia

John Paul II's Legacy as a Resource for Fighting

Totalitarianism: Czechoslovakian Experience

Dr. Katarina Valcova - Comenius University in Bratislava, Slovakia

Reception and Application of John Paul II's Anthropology in Slovakia During His Pontificate

3:20-3:30 Break

3:30 - 5:00 Fifth Concurrent Sessions $A, B, C \& D$

5:00 - 6:30 Sixth Concurrent Sessions (Students'Sessions) A, B, C \& D

January 18, 2020 Day 3

7:00 - 7:30 Holy Mass (optional)

AM Sessions

8:00 - 9:30 Seventh Concurrent Sessions A, B, C \& D

9:30-9:40 Break

9:40 - 11:10 Sixth Plenary Session Moderator: Mr. Alexis Deodato S. Itao Dr. Glenn G. Pajares - University of San Jose-Recoletos (Cebu) Philippines

Karol Wojtyla's Philosophy of the Human Person: A

Means to Understand the Filipino

Rev. Fr. Domingo Delos Angeles, DM, MAPM -

Archdiocese of Cebu (Philippines)

From Juan to John: The Real Story Behind Pope John Paul

II Avenue in Cebu City, Philippines 
11:10 - 11:30 Closing Program

John Paul II March (composed by Fr. Delos Angeles)

Rogationist Seminarians

Closing Remarks Dr. Juan Rafael G. Macaranas

PNPRS Chairman of the Board

11:30 - 12:30 Lunch

\section{Masters of Ceremonies}

Dr. Jiolito L. Benitez and Dr. Fleurdeliz R. Altez-Albela 